\title{
ANALYSIS OF FORBIDDEN PHARMACEUTICAL COMPOUNDS IN ANTIRHEUMATIC JAMU
}

\section{RESMI MUSTARICHIE*, DANNI RAMDHANI, WIWIEK INDRIYATI}

Department of Pharmaceutical Analysis and Medicinal Chemistry, Faculty of Pharmacy, Universitas Padjadjaran, Jatinangor - 45363, Indonesia. Email: rmustarichie@yahoo.com

Received: 01 November 2016, Revised and Accepted: 23 January 2017

ABSTRACT

Objective: To investigate forbidden (by law) pharmaceutical compounds in antirheumatic jamu (herbal medicine).

Methods: Analysis of forbidden pharmaceutical ingredients into jamu was performed using the color reaction, thin layer chromatography (TLC), and densitometry. Color reactions included organoleptic, solubility test and the color reaction, TLC using a stationary phase of silica gel GF 254 and a mobile phase of chloroform; acetone (80:20) was then measured with a densitometer.

Results: Found from 7 herbal antirheumatic known in the market, three of which were synthetic compounds containing paracetamol and dexamethasone additions on one of them.

Conclusion: There was a synthetic drug that was added to the herbal medicine namely jamu sold in the community. The obtained results suggest that the authorities more intensively to monitor the manufacture and distribution of jamu and herbal medicines.

Keywords: Antirheumatic jamu, Herbal medicine, Thin layer chromatography, Densitometer, Paracetamol, Dexamethasone.

(C) 2017 The Authors. Published by Innovare Academic Sciences Pvt Ltd. This is an open access article under the CC BY license (http://creativecommons. org/licenses/by/4. 0/) DOI: http://dx.doi.org/10.22159/ajpcr.2017.v10i4.16101

\section{INTRODUCTION}

In Indonesia, jamu or herbal medicine has been known since long as a traditional medicine processing and utilization are carried down through the generations by prescription heritage, beliefs, culture, and customs of this nation [1-5]. The words jamu derived from ancient Javanese word "jampi" (magic potion) implies the involvement of a magic spell by master traditional healing and the healing of disease by using magic spells or mantra. Herbs or herbal medicine is a traditional medicine that is widely used for the treatment because it is generally cheaper than synthetic drugs and allegedly did not give unwanted side effects as is the case with synthetic drugs [6,7]. According to the Regulation of the Minister of Health [8] of traditional medicine should not contain synthetic chemicals, the result of isolation is efficacious as drugs or narcotics, which are allowed as additives are substances that are not efficacious as a medicine. Jamu must be registered with the BPOM, Indonesian Agency for Food and Drug Administrations, special registration number.

The monitoring results in the market, there are many herbs which included indications that these herbs have medicinal properties, for example, antirheumatic drug doses resemble synthetic drug dosing. This has become one of the considerations of this study to determine whether there was a synthetic drug that was added to the herbal medicine sold in the community. Furthermore, the number of new medicinal plants popping up with a product that is said to be nutritious "drink immediately healed" led to allegations addition of synthetic drugs into it. This article attempts to answer it.

\section{MATERIALS AND METHODS}

\section{Material}

Materials used in the form of jamu antirheumatic from seven different companies, herbal medicine coded as A, B, C, D, E, F and G.

Color reagents used

Solution of sulfuric acid (98\%) $18 \mathrm{M}$, a solution of $1 \% \mathrm{FeCl}_{3}$ reagents, reagent Fehling's solution I, Fehling II and Nessler reagent solution. The color change before and after the addition of reagents is observed in accordance with the reference of Autherhoff [9].

\section{Organoleptic}

Organoleptic inspection to herbal required by Indonesian Pharmacopoeia, Materia Medika Indonesia and Indonesian Herbal Pharmacopoeia [10-16]. These observations included the dosage form, color, taste, and smell of herbs. The color observed after herbal homogenized, Inspection done with less taste tasting substances ways tip of the tongue and the smell examination performed by rubbing the substance on the fingertips and smelt.

\section{Extraction}

The extraction process additives in herbal medicine refer to the Minister of Health [16]. Herbal powder was added to the flask, added extractors which can dissolve the synthetic drugs that may be added to herbal medicine. Shaken until homogeneous and filtered, the filtrate was used for identification.

\section{Reference standards}

As a comparison which was expected to be added as forbidden compounds were antalgin, aspirin, paracetamol, mefenamic acid, ibuprofen, prednisone, and dexamethasone.

\section{Thin layer chromatography (TLC)-densitometer}

Extracts of jamu from the market and reference standards dissolved in certain solvents spotted on TLC plates with silica gel GF254. Let dry and then eluted using the eluent according to the synthetic drugs were examined, namely, the eluent I (chloroform ethanol=90:10, eluent II (chloroform:acetone $=80: 20$, and the eluent III ( $96 \%$ methanol: Concentrated ammonia (100:1.5). Observations were made under light untraviolet $254 \mathrm{~nm}[10,17]$. The dried plates were then put into an TLCscanner and analyzed by densitometer. Peak area of chromatogram sample compared to the peak area standard multiplied by the number of milligrams of substance standard was weighed; the result was expressed in milligrams [18]. 


\section{RESULTS AND DISCUSSION}

\section{Organoleptic}

The composition of each of the jamu used was as follows, jamu A (piperis nigri fructus $15 \%$, massoia aromatic $15 \%$, cinnamomi cortex $10 \%$, zingeberis rhizome $25 \%$, abri folium $20 \%$, orthosiphonis folium $10 \%$, and others $5 \%$ ), jamu B (zingeberis cassumunar rhizome $10 \%$, curcumae rhizome $30 \%$, zingeberis rhizome $30 \%$, kaempferiae rhizome $20 \%$, and myristicae rhizome $10 \%$ ), Jamu C (kaempferiae rhizome $20 \%$, curcumae rhizome $20 \%$, retrofracti fructus $10 \%$, zingeberis aromaticae rhizome $15 \%$, zingeberis purpereae rhizome $10 \%$, parkiae cement $15 \%$, and others $10 \%$ ), jamu D (myristicae cement $10 \%$, zingeberis rhizome $30 \%$, kaempferiae rhizome $20 \%$, curcumae rhizome 30 and others 10\%), jamu E (myristicae cement 10\%, zingeberis rhizome $30 \%$, kaempferiae rhizome $20 \%$, curcumae rhizome $30 \%$, retrofracti fructus $10 \%$ ), jamu $\mathrm{F}$ (zingeberis rhizome $20 \%$, curcumae rhizome $20 \%$, curcumae domesticae rhizoma $20 \%$, retrofracti fructus $15 \%$, and others 25\%), jamu G (kaempferiae rhizome 20\%, 20\% curcumae rhizome, retrofracti fructus $15 \%, 5 \%$ zingeberis aromaticae rhizome, rhizome purpureae zingeberis $15 \%$, and cement parkiae 15\%).

Organoleptic results are shown in Table 1.

\section{Solubility test}

Solubility test was based on the nature of the polarity of each synthetic compound [18]. Solubility test results are shown in Table 2.

\section{Color reaction}

The presence of synthetic compounds can be identified by the use of reagents that can react with the compound being analyzed and will cause a reaction which we can observe that coloration, precipitation, and formation of gases or odors. Some of the color reaction is used for

Table 1: Organoleptic observations

\begin{tabular}{|c|c|c|c|c|}
\hline Jamu & Shape & Color & Sense & Odor \\
\hline A & $\begin{array}{l}\text { Fine } \\
\text { powder }\end{array}$ & Chocolate & Bitter & Typical herbs \\
\hline B & Powder & Yellowish-brown & $\begin{array}{l}\text { Bitter mildly } \\
\text { spicy }\end{array}$ & Typical herbs \\
\hline $\mathrm{C}$ & $\begin{array}{l}\text { Fine } \\
\text { powder }\end{array}$ & Greenish brown & Bitter & Typical herbs \\
\hline D & Powder & Chocolate & $\begin{array}{l}\text { Bitter mildly } \\
\text { spicy }\end{array}$ & Typical herbs \\
\hline $\mathrm{E}$ & $\begin{array}{l}\text { Fine } \\
\text { powder }\end{array}$ & Yellowish-brown & Bitter & Typical herbs \\
\hline $\mathrm{F}$ & Powder & Yellowish-green & $\begin{array}{l}\text { Bitter mildly } \\
\text { spicy }\end{array}$ & Typical herbs \\
\hline G & $\begin{array}{l}\text { Fine } \\
\text { powder }\end{array}$ & Chocolate & Bitter & Typical herbs \\
\hline
\end{tabular}

Table 2: Results of solubility test

\begin{tabular}{llllll}
\hline Substance & Water & Acetone & Ethanol & Methanol & Chloroform \\
\hline Jamu A & +++ & ++ & +++ & +++ & - \\
Jamu B & +++ & ++ & +++ & +++ & - \\
Jamu C & +++ & ++ & +++ & +++ & - \\
Jamu D & +++ & ++ & +++ & +++ & - \\
Jamu E & +++ & ++ & +++ & +++ & - \\
Jamu F & +++ & ++ & +++ & +++ & - \\
Jamu G & +++ & ++ & +++ & +++ & - \\
Antalgin & +++ & - & ++ & ++ & + \\
Mefenamic acid & - & + & + & + & ++ \\
Asetosal & + & ++ & +++ & +++ & ++ \\
Dexamethasone & - & +++ & ++ & ++ & - \\
Ibuprofen & - & +++ & +++ & +++ & +++ \\
Paracetamol & ++ & +++ & +++ & +++ & + \\
Prednisone & + & ++ & + & + & + \\
\hline
\end{tabular}

+++: Soluble, ++: Slightly soluble, +: Poorly soluble, -: Hardly soluble the identification of specific functional groups in the molecule, such as a color reaction with iron (III) chloride to produce red to purple if there is an aromatic hydroxy acid, phenol, enol, pyrazolone, and phenothiazines; for example on aspirin, mefenamic acid, antalgin and paracetamol [9]. The observation of the color reaction can be shown in Table 3 .

Color reaction could only be done on herbal medicine $\mathrm{A}, \mathrm{B}$ and $\mathrm{D}$ because the yellow color of the herbs remains dissolved in the solvent water, acetone, ethanol and methanol. Color reaction at jamu A, B and D was undertaken to ensure the presence or absence of synthetic compounds (paracetamol). Other colors formed from the reaction were difficult to interpret because of the yellow color of the herbs were very disturbing observations.

\section{TLC-densitometer}

TLC carried out on the vessel that had been saturated with mobile phase. The stationary phase used in the form of silica gel GF 254 containing indicator fluorescence (sulfide inorganic) that would emit light when illuminated at a wavelength of $254 \mathrm{~nm}$. Spotting process was done carefully to obtain round and compact spots. The procedure followed the general reference of TLC [19-21].

Table 4 shows TLC results with a variety of mobile phases, while Fig. 1 shows the typical TLC plates used. Each spot was performed in triplo.

The TLC plates were then measured in densitometer as TLC scanner. Measurement based on the reduction of the signal between the light transmitted or reflected by the plate blank part with areas containing the sample. Compounds being analyzed will be able to fluorescenced and measured [22-25]. Chromatogram peak area of substances measured in comparison to the standard substance peak and then multiplied by the number of milligrams of standard substances was

Table 3: Color reaction

\begin{tabular}{|c|c|c|c|c|}
\hline Reagent & Paracetamol & Jamu A & Jamu B & Jamu C \\
\hline $\mathrm{FeCl}_{3}$ & Purple & $\begin{array}{l}\text { Brownish } \\
\text { Yellow }\end{array}$ & $\begin{array}{l}\text { Brownish } \\
\text { Yellow }\end{array}$ & $\begin{array}{l}\text { Brownish } \\
\text { Yellow }\end{array}$ \\
\hline Fehling & Purplish blue & Yellow & $\begin{array}{l}\text { Brownish } \\
\text { Yellow }\end{array}$ & Yellow \\
\hline $\mathrm{H}_{2} \mathrm{SO}_{4}$ & Clear & $\begin{array}{l}\text { Translucent } \\
\text { brownish } \\
\text { Brownish }\end{array}$ & Yellow & Yellow \\
\hline Marquis & Pink & Yellow & $\begin{array}{l}\text { Brownish } \\
\text { Yellow }\end{array}$ & $\begin{array}{l}\text { Brownish } \\
\text { Yellow }\end{array}$ \\
\hline Nessler & $\begin{array}{l}\text { Translucent } \\
\text { Brownish }\end{array}$ & $\begin{array}{l}\text { Brownish } \\
\text { Yellow }\end{array}$ & Yellow & $\begin{array}{l}\text { Brownish } \\
\text { Yellow }\end{array}$ \\
\hline
\end{tabular}

Table 4: TLC with various phases

\begin{tabular}{llll}
\hline Sample & \multicolumn{2}{l}{ Rf values } & \\
\cline { 2 - 4 } & $\begin{array}{l}\mathbf{C H C l}_{\mathbf{3}}: \mathbf{M e O H} \\
\mathbf{( 9 0 : 1 0 )}\end{array}$ & $\begin{array}{l}\mathbf{C H C l}_{3}: \text { Acetone } \\
\mathbf{( 8 0 : 2 0 )}\end{array}$ & $\begin{array}{l}\mathbf{M e O H}: \mathbf{N H}_{4} \mathbf{O H} \\
\mathbf{( 1 0 0 : 1 . 5 )}\end{array}$ \\
\hline Jamu A & 0.155 & 0.316 & - \\
Jamu B & 0.163 & 0.32 & - \\
Jamu C & - & - & - \\
Jamu D & 0.153 & 0.313 & - \\
Jamu E & - & - & - \\
Jamu F & - & - & - \\
Jamu G & - & - & 0.66 \\
Antalgin & 0.668 & 0.518 & - \\
Mefenamic acid & 0.428 & 0.398 & - \\
Acetosal & 0.667 & 0.192 & - \\
Ibuprofen & 0.223 & 0.458 & - \\
Paracetamol & 0.158 & 0.318 & - \\
Dexamehason & - & - & 0.662 \\
Prednisone & - & - & 0.725 \\
\hline
\end{tabular}

TLC: Thin layer chromatography 
weighed and the results expressed in milligrams [26,27]. Measurements were taken at maximum wavelength of $252 \mathrm{~nm}$. A standard curve was made for each plate on level calculation was calculated as the methods spektrofotometry with linear equations. Table 5 shows the results of analysis of illicit substances in Jamu samples. In this research, the yield returns of $97.08 \%$ and $98.01 \%$ for paracetamol and dexamethasone, respectively.

The use of jamu is usually recommended 3 times a day with brewed with $250 \mathrm{ml}$ of water each sachet, meaning if a pack of herbal antirheumatic weight of $7 \mathrm{~g}$ of the herbal medicine contains approximately $450 \mathrm{mg}$ of paracetamol. This is likely to cause the user or customer to think that she was taking the herbs that are effective with not aware of any additional substances into it.

Paracetamol is a painkiller (analgesic) which is actually safe if used according to rules. These drugs are often found in cold medicine component and headache. When mixed into herbs, such as herbs or herbal pegel rheumatic arthritis, it will increase the efficacy of herbal medicine. If only used once or twice is not harmful to health. However, the problem is people generally assume that herbal medicine is safe and they tend to consume every day. If used every day, then paracetamol will accumulate in the body. In large doses, paracetamol can damage the liver/liver causing liver disorders. In the body, will paracetamol is metabolized to produce substances called free radicals $\mathrm{N}$-acetyl-pbenzoquinoneimine (NAPQI). Under normal circumstances, would NAPQI didetoksikasi rapidly by the enzyme glutathione from the heart. In excessive doses, the liver can no longer mendetoksikasinya, and oxygen free radicals can actually damage the liver [28]. Prohibition dexamethasone associated with the following. Dexamethasone is drugs known as corticosteroids who has strong anti-inflammatory effects. If used according to the rules, corticosteroid drugs have many uses, especially in inflammatory diseases, such as rheumatoid arthritis,

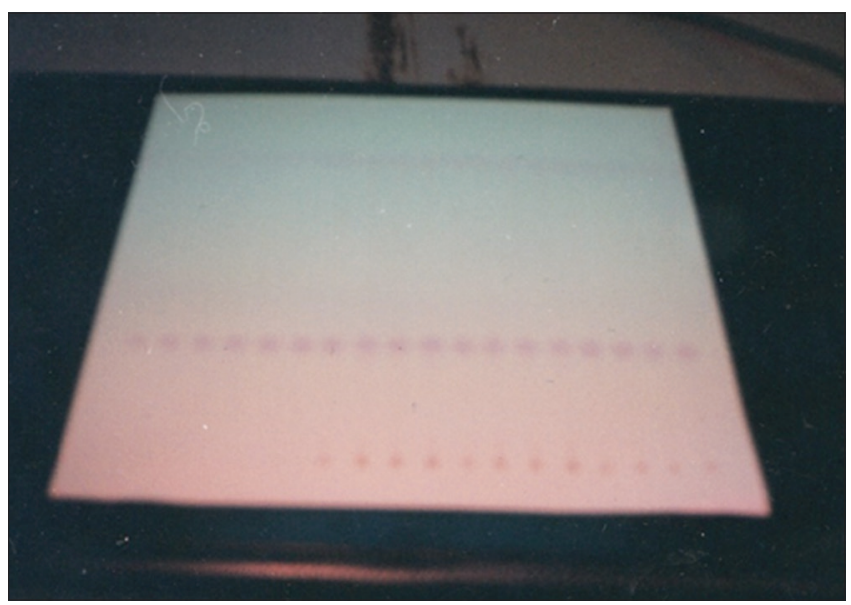

Fig. 1: Typical thin layer chromatography plates used (in this figure using the mobile phase chloroform: Acetone with paracetamol, simulation solution, Jamu A, Jamu B, and Jamu D)

Table 5: The results of the analysis of forbidden substances in Jamu

\begin{tabular}{lll}
\hline Sample & \multicolumn{2}{l}{ \% Forbidden compound } \\
\cline { 2 - 3 } & Paracetamol & Dexamethasone \\
\hline Jamu A & 7.0 & - \\
Jamu B & 6.8 & - \\
Jamu C & - & - \\
Jamu D & 7.5 & - \\
Jamu E & - & - \\
Jamu F & - & - \\
Jamu G & - & 8.0 \\
\hline
\end{tabular}

asthma, allergies, and autoimmune diseases such as lupus, nephrotic syndrome, and rheumatoid arthritis. However, on the other hand, side effects are quite extensive, among others, is to increase blood sugar levels (increasing the risk of diabetes), bone loss (osteoporosis), inhibits the growth of children, cause fat in certain body parts (round face/ moon face, shoulders like humped), causing red streaks in the abdomen (striae), lowered immune system so prone to infection, increasing the risk of hypertension due to hold the salt in the body, causing stomach upset (stomach bleeding), etc. The use of these drugs should not be arbitrary and needs the supervision of the health authorities. If used as directed, of these, side effects can be managed so as not to endanger. Any cessation must not be sudden because it can also be harmful to health. Why is that? Since during the use of corticosteroids from the outside, the production of these hormones naturally from the body stops. If the use of outside suddenly stopped, the body will lack this hormone are normal and will occur reactions are undesirable, such as blood sugar levels fall, the blood pressure drops dramatically from a sitting to standing (orthostatic hypotension), dehydration (lack fluid), weakness, and lethargy. Uncontrolled usage in the form of herbal medicine can certainly increase health risks for patients. Instead of a healthy, even admitted to hospital due to the use of herbs mixed with chemical drugs [29].

Our finding is inline with other researchers except for the methods and type of jamu used. Fauzi [30], for example, identified paracetamol in herbal medicine using TLC and Hafni [31] found their paracetamol in herbal medicine for the treatment of gout. Identification paracetamol in herbal fat healthy for men and women by thin layer chromatographic reported through thesis in 2009 by Siswanti [32]. The presence of paracetamol in herbal stiff circulating in Purwokerto, Mid Java, transparently was reported by Firdaus and Utami [33]. The addition of paracetamol in herbal medicine for uric acid was also found in Samarinda (West Borneo) as to which were reported in 2014 by Nurhasnawati et al. [34]. in Surabaya, East Java, was found the addition of paracetamol and phenylbutazone in herbal medicine stiff reported through thesis by Tourisma in 2011 [35]. By 2015 the identification of the kortikosteroid (dexamethasone, fenilbutazon, and prednisone) content in herbal medicine muscle pains reported by Widyawati et al. [36]. Addition of methampyrone, prednisone, and dexametazon was reported in Serang Province [37]. The results of this study add to the data of other researchers and have proven that there are still many illegal substances were added to the circulating medicinal herbs which are not in accordance with Permenkes No. 246/Menkes/Per/V/1990 although BPOM announced that 54 traditional medicines containing forbidden compound [38]. In constrast to our study, Rukoyah et al. claiming RP-HPLC may be used for simultaneous analysis of four markers, namely, scopoletine, andrographolide, quercetin, and luteolin in antihypertension jamu. The methods can be used to analyze antihypertension jamu formulation in the market [39]. On the other hand, Wisnuwardhani et al. [40] proposed simultaneous analysis of steroid and nonsteroid anti-inflammatory substances in Jamu pegal linu using TLC-spectrophotometry.

We predicted that the addition of paracetamol and dexamethasone were possible because the price of these compounds relatively cheaper and easy to find than other antirheumatic raw materials in Indonesia.

\section{CONCLUSION}

There was a synthetic drug that was added to the herbal medicine namely jamu sold in the community. Of 7 antirheumatic jamu examined, three were found to the addition of paracetamol, and the addition dexamethasone on one type of them. The obtained results suggest that the authorities more intensively to monitor the manufacture and distribution of jamu and herbal medicines.

\section{ACKNOWLEDGMENT}

We are grateful for the technical assistance of Aminah. 


\section{REFERENCES}

1. Tilaar M. The Power of Jamu. Jakarta: Gramedia; 2014. p. 20-5

2. Sakri FM. 1001 Khasiat \& Manfaat Jamu Godoguntuk Segala MacamPenyakit, Efficacy and Benefits of Jamu Godog for All Kinds Disease. Yogyakarta: Diandra Kreatif; 2016. p. 2-4.

3. Sastroamidjojo S. Obat Asli Indonesia (Indigenous Indonesian Medicine). Djakarta: Penerbit Kebangsaan Pustaka Rakjat Djakarta; 1948.

4. Beers SJ. Jamu: The Ancient Art of Herbal Healing. Periplus Editions. Hong Kong: Periplus; 2001.

5. Mustarichie R, Wardhana YW, Wahyudi R. Anti-inflammation of tablet legundi (Vitex trifolia L.) Ethanol extract with variation of sodium starch glycolate. Int J Res Ayurveda Pharm 2016;7(1):114-7.

6. Departemen Kesehatan RI. Kodifikasi Peraturan Perundang-undangan Obat Tradisional (Codification of Legislation of Traditional Medicine). Jakarta: Dirjen POM; 1985. p. 67-9.

7. Tilaar M, Widjaja B. The Tale of Jamu, The Green Gold of Indonesia. Jakarta: Gramedia Pustaka Utama Publisher; 2015. p. 26.

8. Departemen Kesehatan RI. Indonesia's health minister regulations no. 246/Menkes/Per/V/1990 Clause 2, 23.

9. Autherhoff KH. Drug Identifications. Edisi IV. Translated by Sugiarso. Bandung: Penerbit ITB; 1987. p. 28-32.

10. Departemen Kesehatan RI. Farmakope Indonesia. Edisi III. Jakarta: Departemen Kesehatan RI; 1979. p. 43, 190, 196.

11. Departemen Kesehatan RI. Farmakope Indonesia. Edisi IV. Jakarta: Departemen Kesehatan RI; 1995. p. 31, 43, 286, 449, 537, 649, 696, 920.

12. Departemen Kesehatan RI. Materia Medika Indonesia. Jilid I. Jakarta: Departemen Kesehatan RI; 1977. p. 13, 17, 43, 80, 84.

13. Departemen Kesehatan RI. Materia Medika Indonesia. Jilid II. Jakarta: Departemen Kesehatan RI; 1978. p. 51, 60, 103, 118.

14. Departemen Kesehatan RI. Materia Medika Indonesia. Jilid III. Jakarta: Departemen Kesehatan RI; 1979. p. 29, 67, 78, 92, 109.

15. Departemen Kesehatan RI. Materia Medika Indonesia. Jilid IV. Jakarta: Departemen Kesehatan RI; 1980. p. 105.

16. Depkes RI. Materia Medika Indonesia. Jilid V. Jakarta: Departemen Kesehatan RI; 1989. p. 370, 376.

17. Departemen Kesehatan RI. Indonesia's health minister regulations no. 246/Menkes/Per/V/1990 Clause 11.

18. Moffat AC. Clarke's Isolation and Identification of Drugs. $2^{\text {nd }}$ ed. London: Pharmaceutical Press; 1986. p. 160-5.

19. Munson JW. Analisis Farmasi Metode Modern (Pharmaceutical Analysis: Modern Methods), Translated by Harjana. Surabaya: Airlangga University Press; 1991. p. 125-42, 380-2.

20. Bobbitt JM, Schwarting AE, Gritter RJ. Introduction to Chromatography. Vol. 19. New York: Reinhold Book Corp; 1968. p. 478-8.

21. Lewis HW, Moody CJ. Experimental Organic Chemistry: Principles and Practice. Oxford: WileyBlackwell; 1989. p. 159-73.

22. Stahl E. Thin Layer Chromatography, Laboratory Handbook. New York, London: Springer-Verlag, Academic Press; 1963.
23. Ewing GW. Instrumental Methode of Chemical Analysis. $5^{\text {th }}$ ed. New York: Mc-McGraw-Hill Company; 1985. p. 165-6.

24. Fried B, Yoseph S. Thin Layer Chromatography. $3^{\text {rd }}$ ed. New York: Marcel Dekker, Inc.; 1994. p. 177-95.

25. Anggreani DL, Rusdi B, Aprilia HW. Analysis Paracetmol and Dexamethason in Jamu Pegal Linu by Solid Phase Extraction and HPLC, Prosiding Penelitian SpeSia Unisba. Bandung: Indonesia; 2015. p. $104-10$.

26. Knowles A, Burgess C. Practical Absorption Spectrometry Ultraviolet Spectrometry Group. London: Chapman and Hall Press; 1984. p. 190-5.

27. Munson JW. Quantitative thin layer chromatography in pharmaceutical analysis. Drugs Pharm Sci 1984;11:155-78.

28. Anderson BJ. Paracetamol (Acetaminophen): Mechanisms of action. Paediatr Anaesth 2008;18(10):915-21.

29. Merck \& Co, Inc. Product Information. Decadron (Dexamethasone). West Point, PA: Merck \& Co, Inc.; 2001.

30. Fauzi. Thesis. Available from: http://www.openaire.eu/search/ publication? articleId $=$ od-1717, 2012. [Last downloaded on 2016 Jan 02].

31. Hafni E. Available from: https://www.researchgate.net/ Researcher/44185458 Elida_Hafni. [Last downloaded on 2016 Jan 02].

32. Siswanti E. Thesis; 2009. Availbale from: http://www.123dok.com/ document/29062-identifikasi-parasetamol-dalam-jamu-gemuksehat-untuk-pria-dan-wanita-secara-kromatografi-lapis-tipis.htm (identification-paracetamol-in-herbs-fat-healthy-for-men-and-womenin-TLC.htm). [Last downloaded on 2016 Jan 02].

33. Firdaus MI, Utami PI. Paracetamol qualitative analysis on Jamu antirheumatic marketed in Purwokerto. Pharmacy 2009;6(2):1-5.

34. Nurhasnawati H, Rahmuyis, Azmi DA. Prosiding Seminar Nasional Kimia; 2014.

35. Tourisma T. Thesis; 2011. Available from: http://www.repository.wima. ac.id/515/1/ABSTRAK.pdf. [Last downloaded on 2016 Jan 02].

36. Widyawati E, Rusdi B, Maulana IT. Prosiding Penelitian. Bandung, Indonesia: SPeSIA Unisba; 2015. p. 525-30.

37. Kompas (Newspaper), Jakarta, Tuesday, 22 March 2011, BPOM Found Illegal Jamu in Serang Province.

38. BPOM Announces 54 Traditional Medicines Containing Medicinal Chemicals (BKO). ). Media Konsumen . 30 November 2015. Available at http://mediakonsumen.com/2015/11/30/berita-konsumen/bpomumumkan-54-obat-tradisional-mengandung-bahan-kimia-obat-bko

39. Rukoyah U, Fidrianny I, Ruslan KW. Method development for simultaneous analysis of marker scopoletine, and rographolide, quercetin and luteolin in antihypertension jamu formulation using RPHPLC. Int J Pharm Pharm Sci 2014;6(1):534-7.

40. Wisnuwardhani HA, Fidrianny I, Ibrahim S. Method development for simultaneous analysis of steroid and non steroid antiinflammatory substyances in Jamu pegal linu using TLC-spectrophotometry. Int J Pharm Pharm Sci 2013;5(4):749-53. 